\title{
Possibilities and Limits of a Multi/Intercultural Music Appreciation at Schools
}

\author{
Cristiane Abreu Migon and Monique Andries Nogueira \\ Federal University of Rio de Janeiro, Brazil
}

\begin{abstract}
This paper contains reflections from a work in progress research that aims to analyze the possibilities and limits of a multi/intercultural music appreciation at schools. The research takes place in a Brazilian public school and defends the critical multiculturalism, which has the conception of social transformation and it studies issues engaged with the difference. Furthermore, this work in progress research refers to the historical concept of Critical Theory as a way to value the contributions of the philosopher Theodor W. Adorno in education that, basically, develops the formation of conscious, emancipated, and free individuals in society. An adequate hearing and conscious listeners, according Adorno, in music education, are necessary from the concept of music appreciation as an aesthetic expression to musical development of pupils in schools. This article also discusses the possibilities and limits of a repertoire in multi / intercultural music appreciation. In order to make it a pedagogical practice that problematizes issues of discrimination and social exclusion in the routine of schoolchildren, it is important to define the repertoire that will be used. This paper supports the Adorno's criticism about the new mass music of the Culture Industry.
\end{abstract}

\section{Introduction}

As music teachers in a public school and a college course of teacher education, in the city of Rio de Janeiro, we recognize that the school days of pupils are full of prejudiced practices, in which the differences - of ethnicity, class, disability or sexual orientation - are the target of oppression.

Music education, in Brazilian primary schools, resemble what Walker claims to be the '...music lesson where all pupils below a certain age, and a proportion above that age, take music classes not to learn performance but to learn about music...' [18].

A repertoire based on massification perspective, restricted to the production of the Culture Industry, in which sexist and homophobic references are frequent in Brazilian mass music, do not assist the pupils to develop the formation of their personality and appreciation of cultural diversity.

The new mass music, according Adorno, has a regressive role that "plays in the psychological household of its victims" [2]. We can call these victims, according the author, regressive listeners.
To the music teacher, becomes a challenge to work with issues related to cultural diversity, beyond to be complex by integrate the interests of several students in the classroom.

The multi/intercultural music appreciation assists the teacher in music education in that challenge. The approach of an intercultural perspective develops the interaction among different cultural groups and is based on recognition of the difference and in the fight against discrimination or social inequality.

The formulation of multiple ways in which the difference is engaged and constructed is related with the existence of different concepts of multiculturalism. For some authors, the term is polysemic and there are, at least, four different types of multiculturalism: the conservative, liberal, leftliberal and critical.

McLaren proposes and recognizes that the characteristics of the four multicultural perspectives, creates a mixture that interpenetrates in the social practices [15]. However, the critical multiculturalism, defended by McLaren and Candau, is the most suitable in this investigation [4] [15].

The critical multiculturalism argues that diversity should ensure a policy of commitment to social justice, paying attention to the concept of difference, which must be regarded as a product of history, culture, power and ideology.

This perspective assumes that all kinds of representations, are the result of struggles and social transformations of discriminated groups and should not be reduced to an issue of academic production.

In the last 30 years, the impact of intercultural education, in the Latin American Continent, has transformed society and educational systems. This research supports the relationship between interculturalism and multiculturalism.

Although some authors argue that the terms are opposed, Candau considers that this relationship interacts in different socio-cultural groups, '...encouraging dialogue among the subjects, their knowledge and social practices...' [5].

From the polysemy of term, the incorporation of critical intercultural approach, defended by Candau, is based on critical multiculturalism, which gives priority to a political transformation as a product of social struggles [4] [15].

The school enables the predominance of a logical homogenization, without to overcome the cultural differences. Besides, we find ourselves in a world 
marked by an exclusive globalization based on a monocultural perspective.

Difficulties to insert the intercultural critical perspective in schools becomes a challenge, although the analysis of current researches, points to educational practices more susceptible to difference.

This research aimed to combine the questions from multicultural perspective with the approach of Critical Theory. Although not a common combination, the fact comes of an interest by insert a music education that promotes a dialogue between the music educator and pupils as a way to emancipation and expansion of musical knowledge.

According to Adorno, the cultural formation has two facets: the adaptation and emancipation.

Adaptation is the way in which the individual takes possession of knowledge and values of their community. Adaptation is necessary for an individual link with his group: '...culture is adaptation because it is a field in which the individual connects with their social group [13].

On the other hand, culture is also emancipation. This is caused by the assimilation of knowledge already produced '.. extend our horizons, meet other realities, other worldviews, constitute us from unique and original form...' [13].

Considering the adorniano ideal of formation, we searched to support an "education for emancipation, trough a good quality repertoire, intercultural and critical...' [13].

The central ideas of this paper are structured by items, synthesized as follows: 1) the approach of critical multiculturalism/critical intercultural as recognition of differences; 2) the historical concept of Critical Theory and Adorno's contributions in education; 3) the practice of music appreciation as an aesthetic expression, using the theoretical concept of different types of musical conduct; 4) possibilities and limits of a multi/intercultural music appreciation in pupil's musical knowledge, in the recognition of cultural diversity, in music teaching as a musical practice a.gainst oppression and social exclusion in school life.

\section{Concept of Critical Multiculturalism: an Intercultural Approach in Brazilian Schools}

Multiculturalism is the movement of ideas toward democratization, putting it in constant movement and there is no way to ignore multicultural issues in Brazilian schools. It recognizes the diversity among cultures, where cultural aspects play an important role in students learning. Such importance is occasioned because the world, in present days, is increasingly diverse.

This perspective has relation with the diversity that, according to Silva, he defines it as '... a policy of tolerance and respect for different cultures...', and considers that '...contemporary society is characterized by its cultural diversity...' [10].

The diversity is associated with the centrality of culture through the rise of new technologies, institutions and dominion associated with the Culture Industry that, according to Hall, modified the economic, industrial and cultural spheres.

In the educational context, there is an interaction of multiple cultures within the Brazilian primary schools, which complicates the articulation of new technologies and language codes [19].

According to Hall, the media is seen as a powerful means of circulation of informations in a social group [19]. The shortening of the speed with which images, values and ideas has traveling through it, results in social and global shifts and serious cultural dislocations.

This research supports the critical multiculturalism or interculturalism, to be the most appropriate in the construction of more democratic societies, pluralistic and inclusive. As a theoretical perspective, critical multiculturalism includes race, class and gender as a result of social struggles about signs and meanings, emphasizing changes in social, cultural and institutional relations.

McLaren conceptualizes that the idea of critical multiculturalism, is the creation of a social transformation project, where other types of multiculturalism cannot advance [15]. They can be another form of accommodation because only stays around in reform speech.

The author argues that the critical multiculturalism '...understands representations of race, class and gender as the result of larger social struggles over signs and meanings...' [15]. The signs '...are part of an ideological struggle which creates a particular regime of representation serving to legitimate a certain cultural reality...' [15].

The critical multiculturalism seeks to be aware of the concept of difference. According to Silva '...refers to cultural differences among different social groups, defined in terms of social divisions such as class, race, ethnicity, gender, sexuality and nationality...' [10].

According to Candau, there are several authors and different points of view regarding the concept of multiculturalism and interculturalism [4]. However, a critical intercultural approach is that the most closely approximates to the critical multiculturalism, because it promotes a dialogue among different social groups and an education that recognizes and respects the cultural diversity.

This research supports the view that the difference is intrinsic in educational practices, where the critical interculturalism promotes the inter-relationship among different socio-cultural groups in society. 
Furthermore, it breaks with an essentialist view of cultures and cultural identities, works with the idea to conceive the culture in a continuous process of construction, destabilization and reconstruction. The critical interculturalism encourages dialogue between different knowledge and learning [5].

Paulo Freire's contribution is also present in this investigation, because valorizes an education that respects the culture, the experiences of pupils, where the cultural dimension is present in movements toward social transformation [9].

Furthermore, the author created a dialogical method in the teaching-learning process that becomes closest to the principles of critical interculturalim perspective in education.

The interculturalism proposes an education to the rights of others, promotes respect among sociocultural groups, through democratic and dialogical processes. The polysemy of intercultural term implies the creation of diverse perspectives, constituting a complex field of debates and creative discussions.

In Latin American, as a way to find the dichotomy about the interculturalism, three perspectives can be analyzed. The first, called relational interculturalism '... basically refers to the contact and exchange among cultures and sociocultural subjects...' [6].

The second perspective is called functional interculturalism, which the definition is a '...strategy to promote social cohesion, assimilating the sociocultural groups subordinates in the hegemonic society...', and is '...oriented to reduce the areas of tension and conflict, among different groups and social movements...' [6].

However, the author ensures that these relations in question are the focus of critical interculturalism. This perspective promotes systematic processes of dialogue among socio-cultural groups, knowledge and practices in affirmative conception of social justice, economic, cultural and cognitive.

Equal and dialogical relationships among sociocultural groups, the recognition of difference and the fight against all forms of discrimination and social inequalities, are crucial aspects for the critical interculturalism to be realized in the educational field, also affecting the school curriculum and pedagogical practices.

The homogenization in pedagogical practices, the traditional pedagogic paradigm, the monocultural character of the dominant school culture, could be considered problems for the integration of critical intercultural perspective in educational settings.

Despite of Brazilian educators were favorable to critical intercultural approach in the educational context, the requirement of mandatory content, lack of time and preparation, hinder the inclusion of critical intercultural perspective in their practices.
The relationship among knowledge and learning with cultural diversity, makes possible to work with critical intercultural perspective in music education. A critical dialogue between students and educators that considers the difference as a socio-historical constructions, can promote the interaction among different subjects involved.

Educational policies that promote an articulation among equality and difference, appreciation and recognition of cultural diversity, promotes the insertion of critical intercultural approach on pedagogical practices of educators. Such policies contribute to the construction of a free education that promotes social emancipation of pupils.

\section{Critical Theory}

In this item, the article discusses the historical context about the origin of Critical Theory, explaining the thoughts of Frankfurt School's authors, as well as the influences of Critical Theory inside the Philosophy in that period.

A music education, that value the critical selfreflection in the formation of emancipated individuals, assists in the context of this article. At the same time, the contributions of philosopher Adorno on education are important, where the Critical Theory is an important resource.

In 1923, was created the foundation of the Institute of Social Research by the Austrian economist Carl Grunberg. The initial theoretical project, had a strongly Marxist character. Later, the Institute had investigations of a unique project that contained political and philosophical theorizations. With the collaboration of a group of intellectuals, a creation of a critical theory was elaborated, denouncing an urgent transformation of society.

Originally called the Marxism Institute, where socialist issues and academic reflections would be incorporated, the Institute was connected to the University of Frankfurt. In 1930, Max Horkheimer became the director of the Institute and together with a group of researchers; they elaborated a critical analysis of bourgeois society against issues related to fascism, in the capitalist sphere and to Stalinism, in the socialist sphere.

The group of marxist and german thinkers, published, by the Journal of Social Research, their theoretical interventions, according to Pucci, against philosophical, social, cultural and aesthetic problems, caused by late capitalism [3]. These interventions influenced the Western European thoughts in the years 1940-1970. The Journal of Social Research was the principal registration of the Institute.

The Frankfurt School was the later designation of the Institute. We can summarize some important authors: 
- Max Horkheimer, coordinator of the School of the period between 1930 to 1967.

- Herbert Marcuse, known in Brazil in the 1970 s by the publication of his works in the country.

- Theodor W. Adorno, who replaced the coordination of Marcuse School from 1967 to 1969 and joined the Institute in the late 1930s

- Walter Benjamin, who had a studentship in the period 1933-1940.

- Jürgen Habermas, only surviving thinker that later moved away from the School.

Pucci affirms that the Critical Theory term substituted the Historical Materialism term, terminology disseminated by orthodox and hegemonic Marxism in that period [3]. The Critical Theory term was recognized by a Max Horkheimer article, when he affirmed that '...the Marxian theory was actual, but should care for its thoughts with another critical aspects that are presents in reality approach: the philosophical, cultural, political, psychological and do not be influenced, predominantly, by deterministic economism...' [3].

The group of Marxist orientation, denies some traditional principles of Marx's Theory as:

- The historical inevitability.

- The primacy of the production process in the construction of history.

- The notion that the class struggle, as well as the mechanisms of domination, occurs principally, inside the limits of the work process [20].

The authors of Frankfurt School judge that marxists principles, condemn the positivism because removes the historicity of events and reject the concept of autonomous independent culture of political and economic processes.

The role of culture in society was the most important issue of the group. Under the capitalist system, the culture obeys the requirements of positivist thinking. Because of that, according the Frakfurt's School authors, the culture was reduced to a mere consumer goods industry [20].

The Critical Theory '...considers knowledge in the dialectic of transformation practice of existing social relations...' [11]. The Frankfurt School promotes researches of critical nature, related to the immanent processes of domination of society, beyond to emphasize the obstacles and social emancipation possibilities.

The Frankfurt School authors wrote criticisms about the Enlightenment reason, negative dialectics and unintentional truth. For cultural issues, they wrote about the Culture Industry, the concept of semiformation, culture and civilization. The social approach has been elaborated through the individual and society, one-dimensional society and administered society.

The aesthetic themes were elaborated as form, constellation, aesthetic experience, mimesis and rationality in the art work. By psychological issues, the authors wrote texts about authoritarian personality, prejudice and antisemitism [3].

About philosophy, the thought of this intellectual group was inserted in a particular context of the period from the 17th to the 20th Century, with approximations to psychoanalysis.

According to Pucci, '...even continuing in the horizons of Marxist thought, the authors dialogued critically and intensively with Kant, Hegel, Weber, Nietzsche and Freud...' [3].

In the 17th Century, there is an interest by discoveries and inventions of reason. Kant says that the reason points to the emancipation of man. The reason becomes each one capable to think for himself, without the intervention of another.

Hegel has interest in understanding human life in its totality, making a rescue of Enlightenment reason. Through the meaning of life, brought by Romanticism, which reveals life as a totality and the essence of things, Hegel rethinks the concept of Enlightenment reason. He incorporates the internal movement of things for understand life, even if the reason has been the foundation of everything [3].

The contribution of Sigmund Freud with the interpretations of Marxism, helped the group to a new comprehension of contemporary society. This comprehension was supported in basic structures of society and dynamics developed by individuals inside it.

The group discussed that the ideas of Marx were supported by the presentation of oppressive face of the work, subjecting men to a real state of misery. Adding to this, there is the shock in front of the horror domination of technological reason, emerged by World War I. The thought of these intellectuals could be analysed through the relationship among intellectual autonomy, critical analysis and humanist appeal.

To resume the discussion of civilization and its complex relationships, the group believes in transformation of theory into practice. However, the Frankfurt School has no pretensions to create a single thought, restricted and closed. The group denies the reality, where a theme could be analysed together and can be reopened.

This happens when the Frankfurt School authors analyze a particular issue through articles format. They are unfinished and incomplete, contrary of books, which have conclusions.

Through the thought of Kant, it is proposed the ideal of emancipation of an individual, when 18th century is considered the century of Lights or the Enlightenment. The notion of Enlightenment term, translates the idea of a period whose principal 
purpose, was to free the man from ignorance, darkness and lack of knowledge.

Kant affirms that the men, of this period, are unclear. However, fields are open, where individuals can be free to work and obstacles are reduced to general enlightenment.

About the proposal of Kant, in present days, there is an articulation between the emancipation of humanity and the reflections of Theodor W. Adorno about capitalist system. The proposal converts the science and education in a productive force, where the educational process stays under the economy and the logic of capital.

The thought of Adorno, in reference to man, it is about his capacity for critical reflection, in his freedom and autonomy. Through his ideas, we can think of an education that makes possible a selfreflection by individuals. Besides, an intellectual and political autonomy could form conscious individuals, that act in society whenever necessary.

An education through a critical dialogue among cultures, schools, assists in the exchange of experiences between teachers and students, through a dialogical approach by both sides, making them more democratic. Because of this, education plays a fundamental role to contribute to the training of individuals in society.

The philosopher, sociologist, musicologist and critic of culture Theodor W. Adorno, published the book Dialectic of Enlightenment, in 1947, with Max Horkheimer. This book is considered, according to Gomes, the representative of direction change about ideas of critical theory [9].

The author says that the book, in initial idea, seeks a reflection about the concept of enlightenment, through the writing of culture industry and the analysis of antisemitism.

The study of Dialectic of Enlightenment aims to understand why the rationality of human relations produced a social system that does not create a society where men and women can be free and equal.

Adorno did not write any specific book about education. However, according to Pucci, there are, in his texts, articles about educational issues [3]. The author created three perspectives.

In the first, Adorno's thought do not believe in the affirmative theories, because '...they do not express the libertarian potential that stays inside of contradictions of society...' [3].

The second perspective argues that Adorno's thought is ambivalent, and '... agrees to be hard and to be persistent in criticism about how Brazilian education was historically constituted [3].

The last perspective, investigates the performance of education in present days, through Adorno's thought. The thought can be understood as a negative praxis of education where, in its contemporary sphere, '...knowledge is marked by the same deformation of society that he investigates...' [3].
The concept of Critical Theory, according to Gomes, used by Adorno and Horkheimer, demonstrates the importance of two fundamental principles: the orientation for the emancipation and the critical behavior [11].

In the conception of critical theory of Adorno, it is clear the idea that not makes more sense an emancipatory theory of the working class consciousness. Adorno, according to Gomes, replaced it by critical theory of semiformation of bourgeois class [11].

The challenge that Adorno argued was: how be able to explain and emancipate an individual of conformism by semiformation? Men can get out of manipulation, alienation and enclosure through '...formative processes (educational) capable to promotes a political condition, aesthetic and cultural differentiated...' [11].

\section{Music Appreciation as an Aesthetic Expression}

The music appreciation is regarded as a pedagogical practice that assists the musical development of pupils, through the appreciation of a repertoire that expand the pupil's musical knowledge.

The music appreciation is one of the possibilities of musical experience. To ensure an adequate listening in music education, it is necessary thinking a music appreciation as an aesthetic expression. According Pareyson, the aesthetics term analyzes art through their technical, moral, ethical and social aspects, where the aesthetics takes into consideration the experience of art [17].

The concept of aesthetics, considered as a mode of knowledge through sensitivity and as a contact with experience, brings us the following question: what is the base of musical aesthetics? Lazzarin defines musical work from the appearance of the aesthetics and recognition of music as art, turning it into a possible work to be aesthetically contemplated by persons [12].

The multi/intercultural music appreciation, through a musical aesthetics experience, would be, possibly, a practice of recognition of cultural diversity in school days.

The concept of musical work was crucial to find different types of music listeners. Adorno analyzes the society from a group of listeners or not music listeners, where the structural and properties of music establish the reactions of each type of listeners [1].

According Adorno, the types of music listening refer not only to the taste, customs or musical preferences of listeners, but also refer to an adequate or inadequate listening of listener [1]. In his book Introduction to the Sociology of Music, Adorno 
exemplify the types of music listening in seven different types of listeners [1].

The first type is called the expert. According Adorno, ' ... he would be the fully conscious listener, who tends to miss nothing and at the same time, at each moment, accounts to himself for what he has heard...' [1]. This type of listener is defined by entirely adequate listening.

The type of the good listener establishes wellfounded judgments of hearing, as well as the expert listener. However, the good listener understands the music but he knows nothing about musical structure that the expert listener could analyze, which does not prevent him to enjoy the music with more depth. For some people, this type of listener would be formed in basic schools, through a music education for nonspecialists.

The cultural consumer is the third type and he is well-informed, considered by Adorno, a bourgeois type that '...respects musical as a cultural asset...'. The author establish that the '...structure of hearing is atomistic...' [1].

However, the author argues that '...this attitude runs the gamut from an earnest sense of obligation to vulgar snobbery...'. For the cultural consumer "... the type lies in wait for specific elements, for supposedly beautiful melodies, for grandiose moments. On the whole, his relation to music has a fetishistic touch...' [1].

The relationship of emotional listener with music is less rigid and indirect that the cultural consumer. He listens for his own independent-minded. In other words, he listens away from the object or what is perceived.

$\mathrm{He}$ is easily manipulated, naive and opposed to attempts. He is more intense than the cultural consumer, about an adequate listening. According to Adorno, the cultural consumer would be more available to an adequate listening just for the love of culture [1].

The resentment listener has the ideological question above the music listening and he despises the musical experience. An anti-type to the emotional listener, the resentment listener appropriates the mimetic taboo, the prohibitions of civilization where establish them with the norm of musical conduct.

The ideal of these listeners is a static-musical listening. They sympathize with a musical sectarianism and '...subjectivity, expression - to the resentment listener all this is profoundly linked with promiscuity and that he cannot bear to think of ...' [1].

The type of jazz expert and jazz fan are akin to the resentment listener in sectarian character, in musical spontaneity and both have aversion to the ideal of classical-romantic ideal of music. This type of listener has a character of bondage to the authority and they have '...the inability to conceive music dynamically...' [1].

The Culture Industry dominates the entertainment listener type. For him, the music does not have a meaningful context, but considered as a source of stimuli. Adorno says that '...his specific mode of listening is that of distraction and desconcentration, albeit interrupted by sudden bursts of attention and recognition...' [1]. This type of listening can be compared with addiction. The addicted conduct has a resignation to the situation of social pressure and loneliness, making the reality of his own essence.

Obviously, you can review this typology and reflect about the permanence and changes of this classification [14]. However, our purpose in this article, it is enough recognize that the power of culture industry still imposes the rules of repertoire's choice in school.

In this sense, the conscious music educator enables a wide and rigorous listening with the purpose that the pupils become critical and autonomous listeners.

\section{Possibilities and Limits of a Multi/ Intercultural Music Appreciation}

The music appreciation is one of the most accessible and democratic musical activities, where the listening is an active musical experience and it is essential for the musical development of an individual.

According to França and Swanwick, the music appreciation '...is a legitimate and essential form of engagement with music. Through it, we can expand our musical horizons and our understanding...' [7].

Music appreciation is one of the most important practice in the music learning, where the music educator is responsible for enable pupils to develop this hability and that, perhaps, will be the only which the pupils will have access.

França and Swanwick affirm that the practice of listening different types of music, stimulates a '...repertoire of creative possibilities, where the students can act creatively, transforming, reconstructing and reintegrating ideas in new forms and meanings...' [7].

Several authors point various definitions about music appreciation in schools. However, it is important to note that music appreciation should develop an adequate reflective and critical listening, where the repertoire's choice is also an important aspect to be considered.

Generally, the possibility of musical preferences of students in Brazilian schools, is based around the entertainment music of the culture industry, where listening is supported by recognition of feelings and familiarity with mass music. 
As already indicated by Adorno, for more than six decades, the musical taste becomes synonymous to recognize: people listen what the media shows incessantly [2]. In this sense, the listening of students back to a musical experience that cannot be disentailed of media productions of the culture industry.

About recognition and familiarity of new mass music, as well as the media force in the musical tastes of children, Nogueira affirms that '...children are the target of marketing strategies of the music industry...' [16].

The culture industry, associate with the ideology of monopolistic capitalism, has all the signs of the modern industrial world, where the relations among men become difficult, making them victims of progress and technical domination, which is a powerful tool used by the culture industry.

According to Franco, Adorno says that the mass repertoire cannot be considered autonomous art, whose concept is to free the individual to relate himself with the world, implying as an aesthetic experimentation and a development of technical and productions artistic- aesthetic [8].

The autonomy agrees that, the art configures what the ideology represses, causing in the listener, a radical shock. For Franco, the concept of autonomous art is '... one whose existence is resulted of special work non-productive, non-necessary, nonsocially demanded: of free work, of anachronic nature, gratuitous...' [8].

The multi / intercultural music appreciation seeks an unknown musical repertoire of the pupils, but it stays closer of their cultural manifestations. Through a semi-structured questionnaire, the research looks for to know the musical preferences of students, to subsequently, enter with the unknown repertoire.

A repertoire developed out of the culture industry, that stays closer to the musical experiences of students allows creative action, an elaboration of new readings that, consequently, will have new meanings [7].

The practice of music appreciation should to dialogue with different musical styles, where the student can experiment the musical diversity. This research not denies or excludes the musical preferences of pupils.

The insertion of musical experiences of pupils, in learning music, as a significant based on the pedagogical practices of music educators, assists in this investigation at the first stage of the field research. That stage analyzes the preferences, frequency's practices and musical events of these students through the semi-structured questionnaire.

What this research aims is to define that the multi/intercultural musical appreciation is based on emancipation and expansion of musical knowledge of students in schools of critical and reflective manner, in order to encourage them to value the cultural diversity and respect the difference.

As an example for delimitation in relation to the repertoire, it is necessary to mention, as an example, the content of the composition of a famous Brazilian duet of embolada ${ }^{1}$ that stimulates the violence against homosexuals in a funny way.

Despite this Brazilian duet affirms that the music is a satire of humor's nature, this song can be considered as a repertoire that is not helpful to respect the cultural diversity. This type of depreciative repertoire, could encourage discrimination and homophobia. It is important, from this context, to limit the repertoire of a multi/intercultural music appreciation.

Another type of strategy can happen with familiar musical styles of students, like rap: if it has already previously enjoyed by the students, they have extended their appreciation from unknown music, as a way of working with issues engaged with the difference.

Besides, a few lyrics of rap have content that express the struggle of one group against discriminations and social inequalities. In order to not only expand the musical knowledge of the students, these songs also could make them respect and value cultures of different regions, their customs and traditions.

\section{Conclusion}

This work in progress research aimed to formulate a proposal for music appreciation through an intercultural repertoire, that it could promote the expansion of aesthetic-musical references of students, as well as being an acquirement instrument of solidarity and respectful attitudes to differences.

In this sense, was lived the adorniano principle that the formation is covered doubly by polos of adaptation and emancipation: through the appropriation of a repertoire arising from cultural patrimony (adaptation), was possible to expand standards of listening, and, through them, indicate new forms of coexistence (emancipation).

\section{References}

[1] Adorno, T. W. Introduction to the Sociology of Music, The Seabury Press, New York, 1976.

[2] Adorno, T. W. On the Fetish Character in Music and the Regression of listening. In: J. M. Bernstein (ed.), The Culture Industry: Selected Essays on Mass Culture. Routledge Classics, London; New York, 2001.

\footnotetext{
${ }^{1}$ Embolada is a fast Brazilian rhythm and traditional music active in northeastern region. A form of poetry and song, the embolada contains set refrains that allow singers to organize their dialogue improvisations. For more informations, visit the Cravo Albin Dictionary online.
} 
[3] B, Pucci, "Critical Theory and Education: contributions of Critical theory to the education of teacher" Espaço Pedagógico, 2001, v. 8, pp. 13-30.

[4] Candau, V.M. (Org.) Culture ( $s$ ) and education: between critical and post-critical. DP\&A Publishing, Rio de Janeiro, 2005.

[5] Candau, V. M., (2011a) 'School, Didatic and Interculturalism: current challenges', in J. C. Libâneo; M. V. R. S. (Org.). Didactic and school in a Complex Society Didática. CEPED: Goiânia, pp. 1-14.

[6] Candau, V. M., (2011b) 'Human Rights Education and cultural differences: questions and searches' in Candau, V. M. (Org.). Cultural differences and education: constructing ways, 7Letras: Rio de Janeiro.

[7] C. C, França, K. Swanwick, "Composition, appreciation and performance in music education: theory, research and practice" Em Pauta, Porto Alegre, v. 13, n. 21, 2002, pp. 5-41.

[8] Franco, R. (2007) 'The artist as the hermit who knows the departure time of the next train: on the concept of aesthetic autonomy in the work of T. Adorno' in: Franco, R. B.; Goergen, P.; Pucci, B. (Orgs.). Negative Dialectics, Aesthetics and Education, Alínea Editora Campinas.

[9] Freire, P. Pedagogy of hope: a reunion with the pedagogy of the oppressed, Paz e Terra, São Paulo, 2011.

[10] Koff, A., Valentine, D., Candau, V. M. (2011) 'Equality and difference: representations of teachers in the first segment of the elementary school' in Candau, V. M. (Org.). Cultural and educational differences: building pathways. 7Letras, Rio de Janeiro.

[11] L. R. Gomes, "Critical theory and political education in Theodor Adorno" Revista HISTEDBR On-line, Campinas, 2010, n.39, p. 286-296.

[12] Lazzarin, L. F. (2004) 'An understanding of music experience through critical two 'philosophies' of music education' Thesis (Doctor of Education), University of Rio Grande do Sul, Porto Alegre.

[13] M. A, Nogueira, "Music education in the context of the culture industry: some concepts for the formation of the pedagogue" Educação, Santa Maria, 2012, v. 37, n. 3, pp. 615-626.

[14] M. A, Nogueira, "Adorno and the types of musical behavior: current and limits of a categorization" Revista Interação, 2014, vol. 39, n. 2.

[15] McLaren, P. (1995) 'White terror and Oppositional Agency: Towards a Critical Multiculturalism' in P. McLaren (ed.) Critical Pedagogy and Predatory Culture. Oppositional Politics in a Postmodern Era (London: Routledge, London, pp. 117-144.

[16] Nogueira, M. A. (2005) 'Music and Childhood Education: possibilities of teach in perspective of Childhood Pedagogy' in XIV Annual Meeting of the
Association of Music Education: Anais do XIV Encontro Anual da ABEM, Belo Horizonte.

[17] Pareyson, L. Problems of aesthetics. Martins Fontes, São Paulo, 1997.

[18] R. Walker, "Multiculturalism and Music re-attached to music education", Philosophy of Music Education Review 8, no1, (Spring 2000), pp. 31-39.

[19] S. Hall, "The centrality of culture: notes on the cultural revolutions of our time" Education \& Reality, Porto Alegre, July / Dec 1997, vol. 22, No. 2, pp. 15-46.

[20] Schultz, L. M. J. Por uma pedagogia crítica: reflexões sobre algumas tendências em educação. Educação em Revista, São Paulo, vol. 2, n ${ }^{\circ}, 2001$. 